\title{
On the Scientific Spirit of Renaissance Art
}

\author{
Jinsong Li \\ College of Fine Arts, Tonghua Normal University, Tonghua, 134002, China
}

\author{
Keywords: Renaissance, Fine arts, Science, Spirit
}

\begin{abstract}
The Renaissance is a cultural movement from 14th century to 16th century which was a great turning point in the history of human civilization. It is the New Culture Movement, is a reflection of society's new political and economic requirements of the emerging anti-feudal struggle of the bourgeoisie in the ideological and cultural fields. Although Renaissance in knowledge, in all aspects of society and politics have led to the revolution, but the biggest achievement in the arts should be, through a combination of art and science phase, the creation of many outstanding works of art. This period also there have been many great artists: Brunelleschi, Masaccio, Leonardo da Vinci, Michelangelo, Raphael and so on. They work for the future development of the arts has brought a significant impact.
\end{abstract}

\section{Origin and development stage of European Renaissance art}

Renaissance is an ideological and cultural movement taken place in the 14-16 century. It was first developed in the 14th century, because people thought that the Pope and the shackles of theology, so first in Europe, Italy broke the rule of feudalism, the emergence of a capitalist economy to grow. They first weakened the rights of the Pope, followed by the destruction of the church, theological worldview, and finally eradicate the feudal system, ensuring that the people's minds freed from the bondage of theology and religion is a great ideological liberation movement. Prompted the European science and culture has been greatly improved, therefore the Renaissance thus formed. Renaissance art is also affected by this movement began to move forward, and achieved a high achievement, this period has also emerged a number of talented artists.

\section{The spirit of the Renaissance art}

\section{Humanistic spirit}

Humanistic spirit also has a very important idea in art, their thoughts and activities in depth the various sectors of social life. Representatives of these areas have Italian Petrarch, Boccaccio also on behalf of France, Bi, British Moore, their purpose is to absorb more nutrients thought to explore the need for more, explore more theoretical Know how. Art a great breakthrough, representatives of the Italian Leonardo da Vinci, Galileo, Copernicus, Poland, the United Kingdom Moore et al., Appeared in this period a lot of talent. Their development and intellectual development areas materialist society provides an important role.

Humanism had a significant impact on the culture and art emerged in Renaissance. It is a profound ideological content, highly artistic profile, structure and image of thousands of people and freedom of vivid and powerful language, clear figures showed that time and then the history of the real situation. Art of this historical period successfully promoted the development of European art, laid the foundation for the modern bourgeois culture, while cultural development of capitalism has made tremendous contributions.

\section{Scientific spirit}

In Renaissance period, there were changes of social reality and dissemination of humanism, when there has been an unprecedented European "scientific revolution." Form a "scientific revolution" reflects the thinking has been rescued from the natural sciences shackles of medieval theology, but 
also to promote the idea of innovation and progress of society, but also for Western society to a modern process left a monumental history from ancient time's chapter.

Renaissance art and science are closely linked, in the field of painting in perspective, anatomy, and light and shadow appear, become three pillars in the field of painting, so the painting becomes a real art for art career development of the foundation.

\section{Representatives of Renaissance art and historical influences}

\section{Representatives and representative works of European Renaissance art}

Representative works of representative artists in early European Renaissance

Donatello (1386-1466), who is the 15th century's most prominent sculptors of the Italian Renaissance, is the first generation of artists. Donatello's life created a lot of vibrant and solemn calm sculptures, most notably 1430--1432 created out of the first pieces of ancient nude statue - "David." "David" was born as people demonstrate whether a body proportion, or structure are very accurate image of a young boy, he combines the ancient Greek way to create a composition corresponding to the composition mode, when this patterning method of art create a tremendous value.

Masaccio (1401-1428), he is in the process of development during the Renaissance painting significant impact on a key figure because he completely out of the late Gothic style of painting, to promote the real image and true shape of the space, he was also the first a use perspective painter, his first painting in introducing the vanishing point. Masaccio's most representative works is a large mural depicting religious themes - "the tribute money" created during 1425-1428, the mural demeanor and action figures are from the relationship between the characters and their own inner psychological to characterize the state, did not deliberately emphasize shadow decorative and Gothic painting, although the figure may be some awkward body treatment, but it reflects the reality and the real intuitive sense, this painting style is Masaccio's artistic features.

Representative works of representative artists of the European Renaissance (Renaissance heroes) Painting style and his representative works of Leonardo da Vinci

Leonardo da Vinci (1452-1519), is a key figure in the European Renaissance, was a scientist, inventor, painter by modern scholars as "the most perfect representative of the Renaissance," is rare in the history of the whole only. But undoubtedly the greatest achievement of his life painting, his painting techniques advocated from light to dark and the screen must be level, as well as smoke as excessive sense and render a sense of strong, and because the brightness of the image of the flat painting technique more three-dimensional. Leonardo da Vinci painting mostly the people, because he thinks the most beautiful paintings of nature the object is the body, and began to study and dissect the human body, his life dissected with dozens of different sex and age of the human body, but also to draw a number of human bones graphics, is the first concrete depicts spine double S-type people, so he should be to promote human painter painting objects. Da Vinci created many outstanding paintings in his entire life; the most representative works include "Mona Lisa", "The Last Supper," "Virgin of the Rocks" and so on.

"Mona Lisa" is a portrait work which enjoys great popularity all over the world and it represents the highest achievement of Leonardo da Vinci represents in the arts. This painting depicts a sitting elegant, with a mysterious smile, the background scenery around, vividly showing peculiar brushwork painter, artist trying to make the facial expression and rich inner emotions combine to make the picture more colorful. Portrait mouth parts that a mysterious smile, is brought to the screen a sense of mystery, this smile is art historian called "the mysterious smile." And Leonardo da Vinci in the composition side broke the previous bust and bust, this figure is a front bust composition, its slightly biased perspective on the pyramid, can reflect the character more correct and elegant. Also Leonardo da Vinci depicts a pair of soft, precise, plump hand, you can show the character's identity and status, while there is another gentle side. Leonardo da Vinci painting shows exquisite painting techniques and his keen ability to observe things.

Style and representative works of Michelangelo 
Michelangelo (1475-1564) is the greatest sculptor, painter, architect and poet in Italian Renaissance, who was the highest representative of sculpture at that time. Michelangelo and Leonardo da Vinci features emphasis on spiritual and philosophical exploration of science is different, he is put all his energies are devoted to the creation, with its ability to create, enough to show his art career filled with the blood of the spirit. His life created a lot of influence of major works of art, the art of life, the pursuit of perfection; insist on their own artistic style and ideas. His works of art with a strong heroism, shaping the characters are full of strength, perseverance, decisive heroism characters, and vivid image of the heart when people express the ideals and hopes. Representative works are "David", "Genesis" and so on.

"David" is a sculpture of 2.5 meter high, affectionate firm, eyes of God, watching the front side, left hand holding the trebuchet chord, left leg first. Michelangelo statue is entrusted with the desire to get rid of the invaders, this piece is also a brave, steadfast fighter's image, is a milestone sculptures. "David," the emergence of not just a statue of outstanding sculptures, which better reflect the ideological liberation movement in the art of the perfect expression and interpretation of it, anatomical science closely linked with this picture, character modeling and body all parts are shaped by accurate, this is a great sculptures.

Painting style and his representative works of Raphael

Raphael (1483-1520) is a famous Italian Renaissance painter, who is the youngest one in "Renaissance heroes". Raphael is gentle, elegant, so his painting style is quiet, harmonious, and symmetry style. Rafael little creative life hero, he likes to create gentle and beautiful image of the Virgin and Child, he described the woman has its own personality; with each character do not want to, he put the best foot forward women. It created a lot of Madonna, representative works are "Sistine Madonna," "School of Athens", "Madonna del Prato" and so on.

"The School of Athens" is the most representative work of Raphael, which is the introduction of a pair of the people consciously awake intellect and magic works, when linked with the creation of clever features of the building, expanding the spatial effects of the building itself make the building more spacious, spectacular. Raphael has his own style of painting, still painting process combined with clever architectural decoration, make mural art reached its peak position. Painter stepped adept at painting, the stagger between people, so that the screen has a primary and secondary, the real, in sharp contrast. This painting scene is very grand, the characters are numerous, and portray the characters facial expressions and gestures are very vivid, the development of the Renaissance painting to the summit.

\section{Historical influence of renaissance art}

1). Renaissance has fully affirmed the people's own ability, mainly affirmed the human ability to create, to explore a person has unlimited potential to break the shackles of feudalism, the liberation of human nature, to regain the freedom of rights. Requirements should pay attention to their own values, to unleash the creative ability and intelligence itself has, should oppose negative thoughts and life, ideal indifferent attitude towards life, promote positive, innovative and adventurous life values.

2). Pay attention to earthly life, against illusory myths and legends about the afterlife or heaven various oppose the proposed religious asceticism, should the pursuit of happiness and ideological material satisfaction. In literature and art should express the people's thoughts and feelings, against hypocrisy and distortion of reality.

3). The importance of scientific experiments, emphasizing the use of human reason, the development of a unique personality, against transcendentalism, blind obedience, imprisoned humanity, self-restraint. Advocates promoting moral and spiritual development, career development and objectives and moral life have an important relationship. People have the spirit of optimism, optimism life advocates have attitudes and values. The curiosity and the spirit of exploration, in order to better create real-world happiness, so it should have a positive, optimistic, struggling spirit.

4Efforts to rescue the people from the Middle Ages theological opinions out, so that people understand the true nature of Christian theology, the bourgeoisie is in this spirit guidelines created modern capitalist society the next step. Development of the Renaissance movement broke the 
theological doctrine of religious domination, promote and direct impact on the success of the reform movement in religion as the most immediate help. Renaissance claim to have a new understanding of life, against the authority of theological point of view, the ultimate is to awaken people to the Catholic Church and theology of suspicion and disgust, as well as re-understanding. In theology at the core of the philosophy of unity of the situation it was successfully broken the Renaissance, and promote the ideological liberation movement, for the further development of capitalism provided the conditions. Get rid of a superstition, thought the idea of liberation.

In summary, the greatest value is to restore the rationality of the Renaissance, dignity and the ability to think for they possess. Renaissance achievements in the field of philosophy, although not the biggest, but they successfully destroyed the stiff stubborn scholastic system, advocates use the scientific method and experimental verification. Thus, the Renaissance created a lot of exquisite works of art, but also for the development and progress of the arts has made outstanding contributions. Thus, the Renaissance is a most durable and most extensive influence of ideological and cultural movement, which in the field of conscious thought, the success of the human mind freed from feudalism and religious theology, liberation of human ideology, promote the development of European thought and culture, and ultimately promote the development of the cause of art for arts has opened up a broad road.

\section{References}

[1] Liu Minghan. History of European Renaissance. Beijing: People's Publishing House, 2008.

[2] Xia Jiguo. Renaissance in 12th Century. Shanghai: Shanghai People's Publishing House, 2005.

[3] Yuan Kun. Days of Renaissance. Beijing: New World Press, 2011.

[4] Liu Huimin. Maestro on art(first volume) Culture and Art Publishing House, 1987.

[5] Yang Shenyuan. Summary of Western Fine arts theory Nanjing: Jiangsu Fine Arts Publishing House, 1990.

[6] Chang Youming. Modelling art aesthetics Hangzhou: Zhejiang Fine Arts Publishing House, 1987.

[7] Dai Mian(Translator). Leonardo DA Vinci: Treatise On Painting Beijing: People's Fine Arts Publishing House, 1979.

[8] Wu Zeyi. Giants in Renaissance. Beijing: People's Publishing House , 1987.

[9] Meng Guanglin. History of European Renaissance. Beijing: People's Publishing House, 2008.

[10]Wang Tingzhi et, al. Dawn Of A New Century: Renaissance. China Youth Publishing House, 1998. 